\title{
The gettering effect of dielectric films for silicon solar cells
}

DOI:

10.1109/PVSC.2017.8366084

\section{Document Version}

Accepted author manuscript

Link to publication record in Manchester Research Explorer

\section{Citation for published version (APA):}

Liu, A. Y., Sun, C., Markevich, V., Peaker, A., Murphy, J. D., \& Macdonald, D. (2017). The gettering effect of dielectric films for silicon solar cells. In Proceedings of 44th IEEE Photovoltaic Specialists Conference https://doi.org/10.1109/PVSC.2017.8366084

\section{Published in:}

Proceedings of 44th IEEE Photovoltaic Specialists Conference

\section{Citing this paper}

Please note that where the full-text provided on Manchester Research Explorer is the Author Accepted Manuscript or Proof version this may differ from the final Published version. If citing, it is advised that you check and use the publisher's definitive version.

\section{General rights}

Copyright and moral rights for the publications made accessible in the Research Explorer are retained by the authors and/or other copyright owners and it is a condition of accessing publications that users recognise and abide by the legal requirements associated with these rights.

\section{Takedown policy}

If you believe that this document breaches copyright please refer to the University of Manchester's Takedown Procedures [http://man.ac.uk/04Y6Bo] or contact uml.scholarlycommunications@manchester.ac.uk providing relevant details, so we can investigate your claim.

\section{OPEN ACCESS}




\title{
The gettering effect of dielectric films for silicon solar cells
}

\author{
A. Y. Liu ${ }^{1}$, C. Sun ${ }^{1}$, V. P. Markevich ${ }^{2}$, A. R. Peaker ${ }^{2}$, J. D. Murphy ${ }^{3}$, and D. Macdonald ${ }^{1}$ \\ ${ }^{1}$ Research School of Engineering, Australian National University, Canberra, ACT, 2601, Australia \\ ${ }^{2}$ Photon Science Institute, University of Manchester, Manchester, M13 9PL, United Kingdom \\ ${ }^{3}$ School of Engineering, University of Warwick, Coventry, CV4 7AL, United Kingdom
}

\begin{abstract}
We present our recent findings on the strong gettering effect of dielectric films for removing impurities from the silicon bulk. Iron was used as a model impurity in silicon to study the gettering effects. The iron concentration in silicon is found to be significantly reduced after annealing silicon wafers coated with either plasma-enhanced chemical vapour deposited (PECVD) silicon nitride $\left(\mathrm{SiN}_{\mathrm{x}}\right)$ films, or atomic layer deposited (ALD) aluminium oxide $\left(\mathrm{Al}_{2} \mathrm{O}_{3}\right)$ films. Both $\mathrm{PECVD} \mathrm{SiN}_{\mathrm{x}}$ coated and $\mathrm{ALD} \quad \mathrm{Al}_{2} \mathrm{O}_{3}$ coated silicon wafers demonstrate largely diffusion-limited iron reduction rates at around $400^{\circ} \mathrm{C}$, removing half of the bulk iron concentration within $30 \mathrm{~min}$ for a $160-\mu \mathrm{m}$ thick silicon wafer with dielectric films on both sides. PECVD $\mathrm{SiN}_{\mathrm{x}}$ films are shown to achieve diffusion-limited gettering of iron at temperatures below $700^{\circ} \mathrm{C}$, meaning that $90 \%$ of iron can be gettered by the surface $\mathrm{SiN}_{\mathrm{x}}$ films within $5 \mathrm{~min}$ for a $260-\mu \mathrm{m}$ silicon wafer, or within 2 min for a $160-\mu \mathrm{m}$ wafer at $700^{\circ} \mathrm{C}$. Secondary ion mass spectrometry reveals that the gettering effect of PECVD $\mathrm{SiN}_{\mathrm{x}}$ films is caused by impurity segregation into the bulk of the $\mathrm{SiN}_{\mathrm{x}}$ films, and the gettering effect of $\mathrm{ALD} \mathrm{Al}_{2} \mathrm{O}_{3}$ films comes from impurity accumulation at the $\mathrm{Al}_{2} \mathrm{O}_{3} / \mathrm{Si}$ interfaces.

Index Terms - gettering, silicon, iron, silicon nitride, aluminium oxide, plasma enhanced chemical vapour deposition, atomic layer deposition.
\end{abstract}

\section{INTRODUCTION}

Improving the silicon bulk material quality for solar cells is a vital aspect for photovoltaic research and industry. Phosphorus diffusion gettering is commonly applied to remove unwanted impurities in silicon, and the gettering process is conveniently coupled with the formation of $n+$ regions near the silicon wafer surfaces. Effective gettering via phosphorus diffusion, however, relies on the full-area high-temperature heavy diffusion processes, with lighter diffusions or ion implanted phosphorus regions being much less effective at gettering [1-4]. Moreover, novel high efficiency cell architectures, for instance, heterojunction and passivating contact solar cells, no longer require heavy phosphorus or boron diffusion to form $\mathrm{p}-\mathrm{n}$ junctions. The need for alternative gettering processes is therefore imminent. Solar cells based on $n$-type silicon could also benefit from alternative gettering approaches, as the gettering effectiveness of boron diffusion for the formation of $\mathrm{p}+$ regions is thus far not well integrated into cell processing steps [5].

In this paper, we present our recent findings of the strong gettering effect of the commonly used dielectric films for silicon solar cells, namely plasma enhanced chemical vapour deposited (PECVD) silicon nitride $\left(\mathrm{SiN}_{\mathrm{x}}\right)$ films, recently published in Ref. [6], and atomic layer deposited (ALD) aluminium oxide $\left(\mathrm{Al}_{2} \mathrm{O}_{3}\right)$ films, recently published in Ref. [7]. Experimental evidence for the effective gettering capabilities of these two dielectric films is presented. Iron is used as a model impurity in silicon to demonstrate and assess the gettering effect, as dissolved interstitial iron $\left(\mathrm{Fe}_{i}\right)$ in silicon can be easily and accurately quantified using lifetime based techniques [8, 9]. Furthermore, iron is a common efficiencylimiting impurity in silicon solar cells [10]. The gettering effects of PECVD $\mathrm{SiN}_{\mathrm{x}}$ films, and ALD $\mathrm{Al}_{2} \mathrm{O}_{3}$ films, are examined by monitoring the $\mathrm{Fe}_{i}$ concentrations $\left(\left[\mathrm{Fe}_{i}\right]\right.$ ) in the silicon wafer bulk for samples annealed with the respective film coatings, via photoconductance-based carrier lifetime measurements. The re-distribution of iron in the dielectric films and the near-surface regions of the underlying silicon wafer bulk is studied by secondary ion mass spectrometry (SIMS) depth profiling of the iron concentration. A comparison of the gettering kinetics and mechanisms for the two films is presented and discussed.

\section{EXPERIMENTAL DETAILS}

High quality boron-doped float-zone (FZ) silicon wafers, of $1-2 \Omega \mathrm{cm}$, with well-controlled doses of implanted Fe, were used in this study. The wafers were $250-260 \mu \mathrm{m}$ and $160-$ $180 \mu \mathrm{m}$ thick after saw damage etching in an alkaline solution. The targeted volumetric interstitial Fe concentration $\left(\left[\mathrm{Fe}_{i}\right]\right)$ varied from $2 \times 10^{12}$ to $1 \times 10^{14} \mathrm{~cm}^{-3}$. After ion implantation of $\mathrm{Fe}$ atoms, the wafers were annealed at $1000^{\circ} \mathrm{C}$ for $2-3 \mathrm{~h}$ to uniformly distribute Fe throughout the wafer thicknesses. Dry oxygen was chosen as the ambient gas to enable the growth of silicon dioxide $\left(\mathrm{SiO}_{2}\right)$ as surface passivation layers. Some samples were set aside as the $\mathrm{SiO}_{2}$ controls.

A subset of the samples had the $\mathrm{SiO}_{2}$ layers removed in dilute $\mathrm{HF}$, and were then coated with either PECVD $\mathrm{SiN}_{\mathrm{x}}$ films, or ALD $\mathrm{Al}_{2} \mathrm{O}_{3}$ films, on both sides. Details of the PECVD deposition can be found in Ref. [6], and ALD in Ref. [7]. It is worth mentioning that the deposition conditions were optimised for the surface passivation and antireflection purposes, not for the gettering effects.

Quasi-steady-state photoconductance (QSSPC) lifetime measurements [11] before and after breaking FeB pairs via illumination were used to determine the $\mathrm{Fe}_{i}$ concentrations in the Si bulk $[8,9,12]$.

To study the $\mathrm{Fe}_{i}$ reduction kinetics, wafers with either $\mathrm{SiN}_{\mathrm{x}}$, $\mathrm{Al}_{2} \mathrm{O}_{3}$, or $\mathrm{SiO}_{2}$ coatings were co-annealed cumulatively, with 
$\left[\mathrm{Fe}_{i}\right]$ measured after each annealing step using QSSPC. The $\mathrm{SiN}_{\mathrm{x}}$ samples, with the $\mathrm{SiO}_{2}$ controls, were annealed at $250-$ $900^{\circ} \mathrm{C}$; and the $\mathrm{Al}_{2} \mathrm{O}_{3}$ samples, including $\mathrm{SiO}_{2}$ controls, were annealed at $425^{\circ} \mathrm{C}$, a typical passivation activation temperature for the $\mathrm{ALD} \mathrm{Al}_{2} \mathrm{O}_{3}$ films.

The re-distribution of $\mathrm{Fe}$ after annealing silicon wafers coated with different dielectric films was measured by SIMS depth profiling of the $\mathrm{Fe}$ concentration in the annealed $\mathrm{SiN}_{\mathrm{x}}$, $\mathrm{Al}_{2} \mathrm{O}_{3}$ or $\mathrm{SiO}_{2}$ layer and the near surface region of the underlying Si substrate. SIMS measurements were conducted by Evans Analytical Group (EAG) Laboratories.

\section{RESULTS AND DISCUSSION}

\section{A. Reduction kinetics of interstitial iron in silicon wafer bulk}

When annealing silicon wafers coated with either PECVD $\mathrm{SiN}_{\mathrm{x}}$ films, or $\mathrm{ALD} \mathrm{Al}_{2} \mathrm{O}_{3}$ films, significant reductions of the interstitial $\mathrm{Fe}$ concentrations can be observed, as shown in Figs. $1\left(400-425^{\circ} \mathrm{C}\right)$ and $2\left(700^{\circ} \mathrm{C}\right)$.

Fig. 1(a) compares the $\mathrm{Fe}_{i}$ reduction kinetics in samples coated with different dielectric films - PECVD $\mathrm{SiN}_{\mathrm{x}}$, ALD $\mathrm{Al}_{2} \mathrm{O}_{3}$, or thermally grown $\mathrm{SiO}_{2}$. The samples were of the same wafer thickness of $260 \mu \mathrm{m}$, and were annealed at a similar temperature of $400^{\circ} \mathrm{C}\left(\mathrm{SiN}_{\mathrm{x}}\right.$ and $\mathrm{SiO}_{2}$ samples) or $425^{\circ} \mathrm{C}$ $\left(\mathrm{Al}_{2} \mathrm{O}_{3}\right.$ and $\mathrm{SiO}_{2}$ samples). As shown in Fig. 1(a), the $\mathrm{SiO}_{2}$ samples show a much slower rate of $\mathrm{Fe}_{i}$ reduction compared to the $\mathrm{SiN}_{\mathrm{x}}$ and $\mathrm{Al}_{2} \mathrm{O}_{3}$ samples. As evident by the SIMS measurements in Section III B below, the substantial bulk $\mathrm{Fe}_{i}$ losses in the $\mathrm{SiN}_{\mathrm{x}}$ and $\mathrm{Al}_{2} \mathrm{O}_{3}$ coated samples are caused by $\mathrm{Fe}_{i}$ gettering to the surface layers. Therefore, a diffusion-limited surface-loss model from Murphy and Falster [13] is used to fit the measured $\mathrm{Fe}_{i}$ reduction kinetics of the $\mathrm{SiN}_{\mathrm{x}}$ and $\mathrm{Al}_{2} \mathrm{O}_{3}$ samples, with apparent dissolved $\mathrm{Fe}_{i}$ diffusivities being fitting parameters.

The $400^{\circ} \mathrm{C}$ annealed $\mathrm{SiN}_{\mathrm{x}}$ sample yielded an apparent $\mathrm{Fe}_{i}$ diffusivity of $6.5 \times 10^{-9} \mathrm{~cm}^{2} / \mathrm{s}$, and the known $\mathrm{Fe}_{i}$ diffusivity from the literature is $9.6 \times 10^{-9} \mathrm{~cm}^{2} / \mathrm{s}$ [14]. The $425^{\circ} \mathrm{C}$ annealed $\mathrm{Al}_{2} \mathrm{O}_{3}$ sample gave rise to an apparent $\mathrm{Fe}_{i}$ diffusivity of $5 \times 10^{-9}$ $\mathrm{cm}^{2} / \mathrm{s}$, and the reported $\mathrm{Fe}_{i}$ diffusivity is $1.5 \times 10^{-8} \mathrm{~cm}^{2} / \mathrm{s}$ [14]. The $\mathrm{Fe}_{i}$ reduction kinetics in both $\mathrm{SiN}_{\mathrm{x}}$ and $\mathrm{Al}_{2} \mathrm{O}_{3}$ coated samples are therefore close to diffusion-limited surface gettering processes, with the PECVD $\mathrm{SiN}_{\mathrm{x}}$ films being a slightly faster gettering agent than the $\mathrm{ALD} \mathrm{Al}_{2} \mathrm{O}_{3}$ films.

Fig. 1(b) illustrates the $\mathrm{Fe}_{i}$ reduction kinetics in thinner silicon wafers of $160 \mu \mathrm{m}$, which is more typical of the wafer thicknesses used for silicon solar cells nowadays. The silicon wafers were coated with either thermal $\mathrm{SiO}_{2}$, or $\mathrm{ALD} \mathrm{Al}_{2} \mathrm{O}_{3}$ of $20 \mathrm{~nm}$ or $80 \mathrm{~nm}$. As a typical $20-\mathrm{nm} \mathrm{Al}_{2} \mathrm{O}_{3}$ film is too thin for SIMS analysis, the $\mathrm{Fe}_{i}$ kinetics of the $80-\mathrm{nm} \mathrm{Al}_{2} \mathrm{O}_{3}$ coated samples are examined and compared with the kinetics of 20$\mathrm{nm} \mathrm{Al}_{2} \mathrm{O}_{3}$ films, as shown in Fig. 1(b). This serves to ensure that the SIMS measurements on $80-\mathrm{nm} \mathrm{Al}_{2} \mathrm{O}_{3}$ films are representative of the gettering behaviours of typical ALD $\mathrm{Al}_{2} \mathrm{O}_{3}$ films (commonly less than $30 \mathrm{~nm}$ ).

As shown in Fig. 1(b), the samples coated with $\mathrm{Al}_{2} \mathrm{O}_{3}$ films, of either $20 \mathrm{~nm}$ or $80 \mathrm{~nm}$, demonstrate a much faster $\mathrm{Fe}_{i}$ decline compared to the co-annealed $\mathrm{SiO}_{2}$ sample in the initial stages. At this early stage, the $\mathrm{Fe}_{i}$ reduction kinetics can be fitted by the same diffusion-limited surface-gettering model [13] using a fitted diffusivity of $7 \times 10^{-9} \mathrm{~cm}^{2} / \mathrm{s}$. This is similar to the fitted diffusivity of the $260-\mu \mathrm{m} \mathrm{Al}_{2} \mathrm{O}_{3}$ sample shown in Fig. 1(a), indicating that the slower $\mathrm{Fe}_{i}$ kinetics in the $260-\mu \mathrm{m}$ samples are largely due to the different wafer thicknesses. The $\mathrm{Fe}_{i}$ kinetics of the $\mathrm{Al}_{2} \mathrm{O}_{3}$ samples gradually slow down, the cause of which is unclear at this stage, as discussed in Ref. [7].

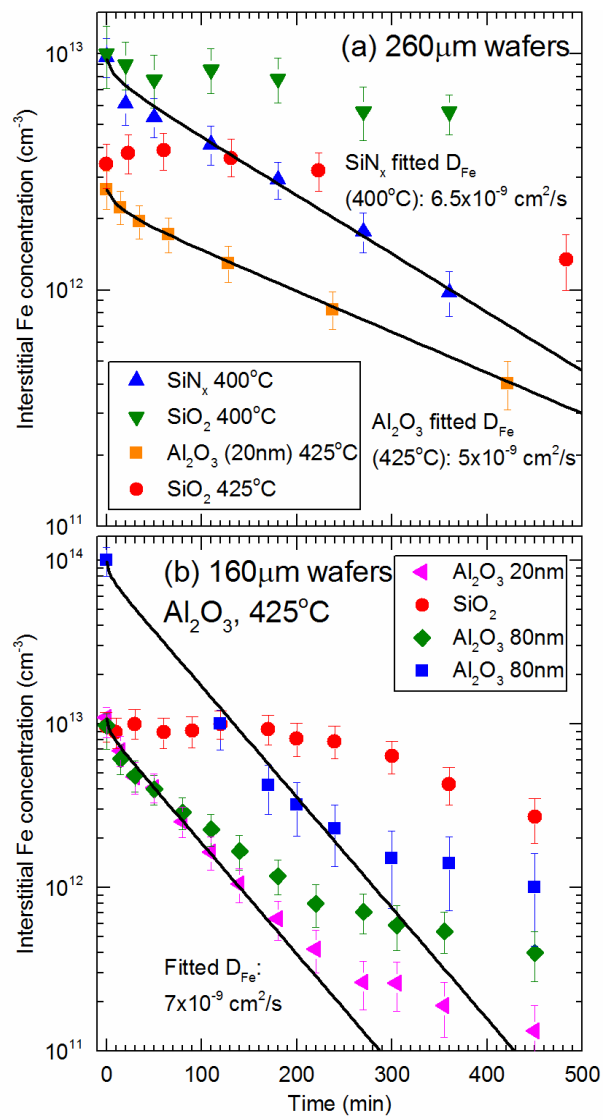

Fig. 1. Measured $\mathrm{Fe}_{i}$ reduction kinetics in the silicon wafer bulk for samples coated with PECVD $\mathrm{SiN}_{\mathrm{x}}, \mathrm{ALD} \mathrm{Al}_{2} \mathrm{O}_{3}$, or thermal $\mathrm{SiO}_{2}$, and cumulatively annealed at $400^{\circ} \mathrm{C}\left(\mathrm{SiN}_{\mathrm{x}}\right.$ and $\mathrm{SiO}_{2}$ samples) or $425^{\circ} \mathrm{C}\left(\mathrm{Al}_{2} \mathrm{O}_{3}\right.$ and $\mathrm{SiO}_{2}$ samples). Fig. 1(a) plots the kinetics for wafers of $260 \mu \mathrm{m}$ thick, with three different dielectric coatings. Fig. 1(b) shows the kinetics of $160-\mu \mathrm{m}$ thick wafers, coated with either $\mathrm{SiO}_{2}$, or $\mathrm{Al}_{2} \mathrm{O}_{3}$ of different thicknesses and two different initial $\mathrm{Fe}_{i}$ concentrations. The straight black lines are fittings to the experimental data based on a diffusion-limited surface-loss model, yielding fitted apparent $\mathrm{Fe}_{i}$ diffusivities [13].

As evident in Fig. 1(b), the $\mathrm{SiO}_{2}$ sample again first shows little change in $\mathrm{Fe}_{i}$ concentration. With increasing annealing time, $\left[\mathrm{Fe}_{i}\right]$ reduction becomes faster. The initial slow change phase may be related to the nucleation of precipitation sites 
that later facilitate $\mathrm{Fe}_{i}$ precipitation to take place, and thus a faster $\left[\mathrm{Fe}_{i}\right]$ decline at later stages.

The measured $\mathrm{Fe}_{i}$ kinetics and fitted apparent diffusivities in Fig. 1 show that, for a typical 160- $\mu \mathrm{m}$ wafer, a 30-min anneal at $400-425^{\circ} \mathrm{C}$ reduces the bulk $\mathrm{Fe}_{i}$ concentration by half. Iron has a moderate diffusivity in silicon. This reported gettering effect should be taken into account in studies that use PECVD $\mathrm{SiN}_{\mathrm{x}}$ or $\mathrm{ALD} \mathrm{Al}_{2} \mathrm{O}_{3}$ films as surface passivation coatings, to avoid misinterpretation. PECVD typically operates at $250-$ $500^{\circ} \mathrm{C}, \mathrm{ALD} \mathrm{Al}_{2} \mathrm{O}_{3}$ films typically require a post-deposition anneal at $300-500^{\circ} \mathrm{C}$, and the processing time ranges from minutes to tens of minutes. This means that the fabrication of these dielectric films could result in considerable bulk impurity gettering effects, depending on the processing conditions, as observed in Refs. $[15,16]$. The external gettering of $\mathrm{Fe}_{i}$ during the passivation step could also explain lower $\mathrm{Fe}_{i}$ concentrations measured in multicrystalline silicon wafers passivated by PECVD $\operatorname{SiN}_{\mathrm{x}}$ compared to temporary liquid passivation schemes $[17,18]$.

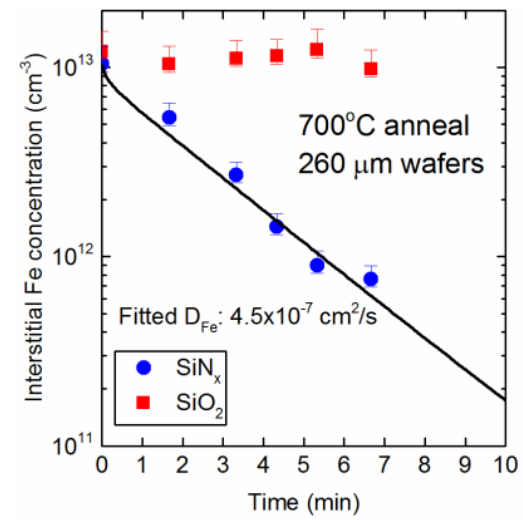

Fig. 2. Measured $\mathrm{Fe}_{i}$ reduction kinetics in $260-\mu \mathrm{m}$ thick silicon wafers coated with either PECVD $\mathrm{SiN}_{\mathrm{x}}$ or thermal $\mathrm{SiO}_{2}$, cumulatively annealed at $700^{\circ} \mathrm{C}$. The straight black line is a fitting to the experimental data based on a diffusion-limited surface-loss model, yielding a fitted apparent $\mathrm{Fe}_{i}$ diffusivity [13].

Fig. 2 presents the $\mathrm{Fe}_{i}$ reduction kinetics at $700^{\circ} \mathrm{C}$ for the PECVD $\mathrm{SiN}_{\mathrm{x}}$ and thermal $\mathrm{SiO}_{2}$ coated samples. Similar to the $400^{\circ} \mathrm{C}$ results in Fig. 1, the $\mathrm{SiN}_{\mathrm{x}}$ sample demonstrates a much faster $\mathrm{Fe}_{i}$ loss than the $\mathrm{SiO}_{2}$ sample, and the loss kinetics can be fitted by the same diffusion-limited surface-loss model [13], using a fitted diffusivity that is close to the reported $\mathrm{Fe}_{i}$ diffusivity (fitted diffusivity is $4.5 \times 10^{-7} \mathrm{~cm}^{2} / \mathrm{s}$, and the reported $\mathrm{Fe}_{i}$ diffusivity is $3.4 \times 10^{-7} \mathrm{~cm}^{2} / \mathrm{s}$ [14]). This indicates a diffusion-limited surface-gettering process at $700^{\circ} \mathrm{C}$ for the PECVD $\mathrm{SiN}_{\mathrm{x}}$ films. In fact, for PECVD $\mathrm{SiN}_{\mathrm{x}}$ films the $\mathrm{Fe}_{i}$ reduction kinetics over a wide temperature range of $250-$ $900^{\circ} \mathrm{C}$ have been investigated in Refs. $[6,15,19]$, and the results show that the $\operatorname{SiN}_{\mathrm{x}}$ gettering process is largely diffusion-limited for temperatures below $700^{\circ} \mathrm{C}$. This helps to estimate the amount of bulk impurity loss for any given temperature profiles below $700^{\circ} \mathrm{C}$.
As shown by the experimental data in Fig. 2, for a $260-\mu \mathrm{m}$ silicon wafer coated with $\mathrm{SiN}_{\mathrm{x}}$ films on both sides, the bulk $\mathrm{Fe}_{i}$ concentration is reduced by $90 \%$ after $5 \mathrm{~min}$ at $700^{\circ} \mathrm{C}$. Modelling of the diffusion-limited surface-gettering process [13] predicates that, for a $160-\mu \mathrm{m}$ wafer with $\mathrm{SiN}_{\mathrm{x}}$ films on both sides, $90 \%$ of the bulk $\mathrm{Fe}_{i}$ is removed within 2 min at $700^{\circ} \mathrm{C}$.

\section{B. Re-distribution of iron}

In order to understand the observed $\mathrm{Fe}_{i}$ reductions in the silicon wafer bulk (Figs. 1 and 2), SIMS analysis was conducted to reveal the re-distribution of $\mathrm{Fe}$ after annealing, in samples coated with different types of dielectric films and annealed for extended time to drive large bulk $\mathrm{Fe}_{i}$ reductions. Note that SIMS detects the total Fe concentration regardless of the electrical state, that is, SIMS detects both dissolved and precipitated Fe atoms.

It is observed that, all of the measured SIMS Fe profiles, in Figs. 3 and 4 and in Refs. [6, 7], demonstrate a near-surface Fe increase, for samples with or without previous bulk $\mathrm{Fe}$ contamination and with different film coatings. This suggests that this near-surface $\mathrm{Fe}$ increase does not come from the gettering of $\mathrm{Fe}$ from the silicon bulk, and is likely a measurement artefact in SIMS analysis, possibly caused by unintentional surface contamination during handling and processing.

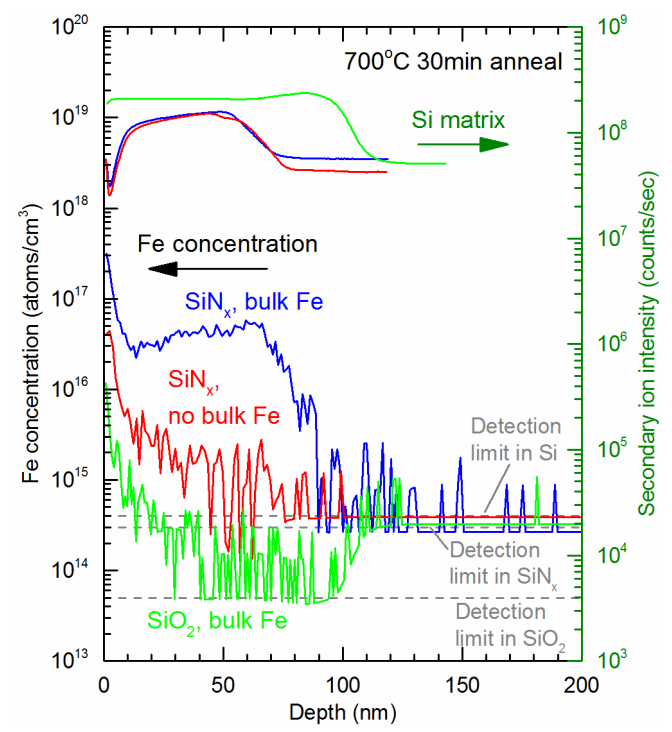

Fig. 3. SIMS measurements of the total Fe distribution in (1) PECVD $\mathrm{SiN}_{\mathrm{x}}$ coated silicon wafer with bulk $\mathrm{Fe}_{i}$ contamination of $10^{13} \mathrm{~cm}^{-3}$; (2) PECVD $\mathrm{SiN}_{\mathrm{x}}$ coated silicon wafer with no bulk $\mathrm{Fe}_{i}$ contamination; and (3) thermally grown $\mathrm{SiO}_{2}$ coated silicon wafer with bulk $\mathrm{Fe}_{i}$ contamination of $10^{13} \mathrm{~cm}^{-3}$. All three samples were annealed at $700^{\circ} \mathrm{C}$ for $30 \mathrm{~min}$ in $\mathrm{N}_{2}$. The upper curves are a qualitative measure of the Si matrixes (plotted against the $\mathrm{y}$-axis on the right), which are used to indicate the positions of the $\mathrm{SiN}_{\mathrm{x}}$ or $\mathrm{SiO}_{2}$ films and the $\mathrm{Si}$ substrate in the depth profiles. The detection limits of total $\mathrm{Fe}$ in $\mathrm{SiN}_{\mathrm{x}}, \mathrm{SiO}_{2}$, and $\mathrm{Si}$ are marked by dashed lines. 
As shown in Fig. 3, a high concentration of Fe is detected in the $\mathrm{SiN}_{\mathrm{x}}$ film for the $\mathrm{Fe}_{i}$-contaminated $\mathrm{SiN}_{\mathrm{x}}$ sample, whereas the $\mathrm{Fe}$ concentration in the $\mathrm{SiO}_{2}$ layer in $\mathrm{Fe}_{i}$-contaminated coannealed $\mathrm{SiO}_{2}$ sample is below the detection limit. This is consistent with the lifetime measurements (Fig. 2 and Ref. [6]) that the $\mathrm{SiO}_{2}$ sample only experienced a small decrease in the bulk $\mathrm{Fe}_{i}$ concentration after a $700^{\circ} \mathrm{C} 30$-min anneal, and hence the majority of $\mathrm{Fe}_{i}$ still remains in the silicon wafer bulk, at a concentration well below the detection limit of SIMS for quantifying $\mathrm{Fe}$ in $\mathrm{Si}$.

The high Fe concentration in the $\mathrm{SiN}_{\mathrm{x}}$ film is shown to arise from the Si bulk, by comparing the SIMS Fe profiles in $\mathrm{SiN}_{\mathrm{x}}$ samples with or without previous bulk $\mathrm{Fe}_{i}$ contamination (Fig. 3). The bulk $\mathrm{Fe}_{i}$-contaminated sample shows a much higher concentration of $\mathrm{Fe}$ in the $\mathrm{SiN}_{\mathrm{x}}$ film, indicating that this high Fe concentration does not come from the PECVD $\operatorname{SiN}_{x}$ deposition or the subsequent annealing processes, but rather from Fe previously distributed in the Si bulk in the interstitial form (i.e. $\mathrm{Fe}_{i}$ ), that is, $\mathrm{Fe}_{i}$ is gettered to the $\mathrm{SiN}_{\mathrm{x}}$ film from the Si bulk upon annealing. The quantitative Fe concentration in the $\mathrm{SiN}_{\mathrm{x}}$ film from SIMS measurements is also found to be similar to the bulk $\mathrm{Fe}_{i}$ reduction measured from QSSPC, further confirming that $\mathrm{Fe}_{i}$ is gettered from the silicon bulk to the surface $\mathrm{SiN}_{\mathrm{x}}$ film.

The uniform Fe distribution in the $\mathrm{SiN}_{\mathrm{x}}$ film (shown in Fig. 3 ), and the effectiveness of $\operatorname{SiN}_{\mathrm{x}}$ gettering at temperatures where the $\mathrm{Fe}_{i}$ solubilities are well above the bulk $\mathrm{Fe}_{i}$ concentrations (shown in Refs. $[6,15]$ ), indicate that the $\mathrm{SiN}_{\mathrm{x}}$ gettering process is driven by impurity segregation into the PECVD SiN $_{\mathrm{x}}$ films.

The observed $\left[\mathrm{Fe}_{i}\right]$ reductions in PECVD $\mathrm{SiN}_{\mathrm{x}}$ coated samples were previously conjectured to be due to the hydrogenation of $\mathrm{Fe}[15,19]$ (and the Refs within). This hypothesis, however, was later found to be inconsistent with the results from deep-level transient spectroscopy (DLTS) analysis of the annealed silicon wafers, and thermal stability studies of the $\mathrm{Fe}_{i}$ reductions, as detailed in Ref. [6]. The SIMS measurements of the $\mathrm{Fe}$ re-distribution provide conclusive evidence for the gettering effect of PECVD $\mathrm{SiN}_{\mathrm{x}}$ films, ruling out the previous hydrogenation hypothesis. Our results do not exclude the possibility of hydrogenation of the silicon from the $\mathrm{SiN}_{\mathrm{x}}$ film, but the involvement of hydrogen is not necessary to explain the kinetics of the interstitial iron reduction observed.

Fig. 4 presents the SIMS results of $\mathrm{ALD} \mathrm{Al}_{2} \mathrm{O}_{3}$ coated and thermal $\mathrm{SiO}_{2}$ coated samples, co-annealed at $425^{\circ} \mathrm{C}$ for an extended $18 \mathrm{~h}$. After the long cumulative anneals, both $\mathrm{Fe}_{i^{-}}$ contaminated samples, with either $\mathrm{Al}_{2} \mathrm{O}_{3}$ or $\mathrm{SiO}_{2}$ coatings, show a significant reduction in the bulk $\mathrm{Fe}_{i}$ concentration (Fig. 1 and Ref. [7]). The SIMS profiles of the two $\mathrm{Fe}_{i^{-}}$ contaminated samples both demonstrate large Fe peaks at the $\mathrm{Al}_{2} \mathrm{O}_{3} / \mathrm{Si}$ or $\mathrm{SiO}_{2} / \mathrm{Si}$ interface. The quantitative $\mathrm{Fe}$ concentrations in these Fe peaks from SIMS measurements show general agreement with the losses of bulk $\mathrm{Fe}_{i}$ concentrations determined from QSSPC lifetime measurements, indicating that the $\mathrm{Fe}$ peaks source from $\mathrm{Fe}_{i}$ originally distributed in the silicon bulk.

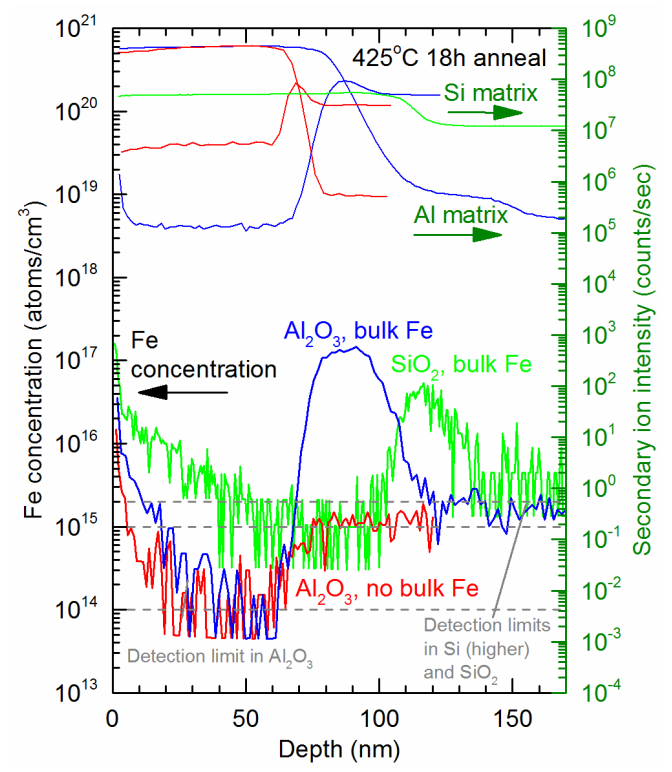

Fig. 4. SIMS measurements of the total Fe distribution in (1) ALD $\mathrm{Al}_{2} \mathrm{O}_{3}$ coated silicon wafer with bulk $\mathrm{Fe}_{i}$ contamination of $10^{14} \mathrm{~cm}^{-3}$; (2) ALD $\mathrm{Al}_{2} \mathrm{O}_{3}$ coated silicon wafer with no bulk $\mathrm{Fe}_{i}$ contamination; and (3) thermally grown $\mathrm{SiO}_{2}$ coated silicon wafer with bulk $\mathrm{Fe}_{i}$ contamination of $10^{13} \mathrm{~cm}^{-3}$. All three samples were cumulatively annealed at $425^{\circ} \mathrm{C}$ for a total of $18 \mathrm{~h}$ in air. The upper curves are a qualitative measure of the $\mathrm{Al}$ and $\mathrm{Si}$ matrixes (plotted against the $\mathrm{y}$ axis on the right), which are used to indicate the positions of the $\mathrm{Al}_{2} \mathrm{O}_{3}$ or $\mathrm{SiO}_{2}$ films and the $\mathrm{Si}$ substrate in the depth profiles. The detection limits of total $\mathrm{Fe}$ in $\mathrm{Al}_{2} \mathrm{O}_{3}, \mathrm{SiO}_{2}$, and $\mathrm{Si}$ are marked by dashed lines.

It is well known in the literature that Fe-silicide precipitates tend to form at the $\mathrm{SiO}_{2} / \mathrm{Si}$ interfaces (see, for example, Ref. [10]). The observed $\mathrm{Fe}$ peak at the $\mathrm{SiO}_{2} / \mathrm{Si}$ interface for the thermal $\mathrm{SiO}_{2}$ coated sample is therefore likely due to $\mathrm{Fe}_{i}$ precipitation, as the solubility of $\mathrm{Fe}_{i}$ at $425^{\circ} \mathrm{C}$ is in the range of $10^{5} \mathrm{~cm}^{-3}$ [14] to $10^{8} \mathrm{~cm}^{-3}$ (from extrapolation [20]), providing sufficient driving force for relaxation precipitation to take place.

As shown in Fig. 4, an $\mathrm{Al}_{2} \mathrm{O}_{3}$ coated sample without previous bulk $\mathrm{Fe}_{i}$ contamination illustrates no such Fe peak at the $\mathrm{Al}_{2} \mathrm{O}_{3} / \mathrm{Si}$ interface. This further confirms that the Fe peak observed in the $\mathrm{Fe}_{i}$-contaminated $\mathrm{Al}_{2} \mathrm{O}_{3}$ sample comes from the gettering of $\mathrm{Fe}_{i}$ from the silicon bulk.

The underlying mechanism for the accumulation of $\mathrm{Fe}$ at the $\mathrm{Al}_{2} \mathrm{O}_{3} / \mathrm{Si}$ interface remains unknown at this stage. As an ultrathin silicon oxide $\left(\mathrm{SiO}_{\mathrm{x}}\right)$ layer is known to reside at the ALD $\mathrm{Al}_{2} \mathrm{O}_{3} / \mathrm{Si}$ interface [21], this $\mathrm{Fe}$ peak may be caused by $\mathrm{Fe}_{i}$ precipitation at the $\mathrm{SiO}_{\mathrm{x}} / \mathrm{Si}$ interface, similar to the $\mathrm{Fe}_{i}$ precipitation at the thermal $\mathrm{SiO}_{2} / \mathrm{Si}$ interface discussed above. However, the $\mathrm{ALD} \mathrm{Al}_{2} \mathrm{O}_{3}$ and thermal $\mathrm{SiO}_{2}$ samples show very different $\mathrm{Fe}_{i}$ loss kinetics, as can be seen in Fig. 1. Hence, $\mathrm{Fe}$ accumulation at the ALD $\mathrm{Al}_{2} \mathrm{O}_{3} / \mathrm{Si}$ interface could be caused by a different mechanism, for example, by impurity 
segregation at the $\mathrm{Al}_{2} \mathrm{O}_{3} / \mathrm{Si}$ interface. Further temperaturedependent gettering studies will be required to assess the hypotheses.

\section{SUMMARY}

This paper presents experimental evidence for the strong gettering effects of the commonly used dielectric films for silicon solar cells: PECVD silicon nitride and ALD aluminium oxide films. The gettering process is found to be largely diffusion-limited for both films near $400^{\circ} \mathrm{C}$. The PECVD silicon nitride films are shown to result in diffusion-limited gettering effects at temperatures below $700^{\circ} \mathrm{C}$. The measured interstitial iron reduction kinetics indicate that significant impurity gettering can be achieved by the dielectric films at moderate temperatures within minutes to tens of minutes, depending on the impurity diffusivity in silicon. International impurity gettering to dielectric films at low temperatures could be a viable alternative to high temperature gettering and may be particularly useful in the development of novel siliconbased solar cells.

Although the two films demonstrate similar diffusion-limited gettering processes at around $400^{\circ} \mathrm{C}$, the underlying gettering mechanisms are different: PECVD silicon nitride films relocate bulk impurities into the films via segregation gettering, and ALD aluminium oxide films getter impurities via impurity accumulation at the $\mathrm{Al}_{2} \mathrm{O}_{3} / \mathrm{Si}$ interfaces.

\section{ACKNOWLEDGEMENT}

This work has been supported by the Australian Renewable Energy Agency (ARENA) through project RND009. Author C Sun acknowledges the financial support from Australian Centre for Advanced Photovoltaics. The work in the UK is supported by the Engineering and Physical Sciences Research Council via the SuperSilicon PV project (EP/M024911/1). We acknowledge access to NCRIS facilities (ANFF and the Heavy Ion Accelerator Capability) at the Australian National University.

\section{REFERENCES}

E. Cho, Y.-W. Ok, L. D. Dahal, A. Das, V. Upadhyaya, and A. Rohatgi, "Comparison of $\mathrm{POCl} 3$ diffusion and phosphorus ion-implantation induced gettering in crystalline Si solar cells," Solar Energy Materials and Solar Cells, vol. 157, pp. 245-249, 2016.

H. S. Laine, V. Vähänissi, Z. Liu, H. Huang, E. Magaña, A. E. Morishige, et al., "Finite- vs. infinite-source emitters in silicon photovoltaics: Effect on transition metal gettering," in 2016 IEEE 43rd Photovoltaic Specialists Conference

(PVSC), 2016, pp. 0678-0680.
M. Kim, H. Li, D. Payne, S. Wenham, B. Hallam, and M. Abbott, "Application of high efficiency emitters to multicrystalline silicon," presented at the 32nd European
Photovoltaic Solar Energy Conference and Exhibition, Munich, Germany, 2016.

V. Vähänissi, A. Haarahiltunen, M. Yli-Koski, and H. Savin, "Gettering of Iron in Silicon Solar Cells With Implanted Emitters," IEEE Journal of Photovoltaics, vol. 4, pp. 142-147, 2014.

S. P. Phang, W. Liang, B. Wolpensinger, M. A. Kessler, and D. Macdonald, "Tradeoffs Between Impurity Gettering, Bulk Degradation, and Surface Passivation of Boron-Rich Layers on Silicon Solar Cells," IEEE Journal of Photovoltaics, vol. 3, pp. 261-266, 2013.

A. Y. Liu, C. Sun, V. P. Markevich, A. R. Peaker, J. D. Murphy, and D. Macdonald, "Gettering of interstitial iron in silicon by plasma-enhanced chemical vapour deposited silicon nitride films," Journal of Applied Physics, vol. 120, 193103, 2016.

A. Y. Liu and D. Macdonald, "Impurity gettering effect of atomic layer deposited aluminium oxide films on silicon wafers," Applied Physics Letters, vol. 110, 191604, 2017.

G. Zoth and W. Bergholz, "A fast, preparation-free method to detect iron in silicon," Journal of Applied Physics, vol. 67, pp. 6764-6771, 1990.

D. H. Macdonald, L. J. Geerligs, and A. Azzizi, "Iron detection in crystalline silicon by carrier lifetime measurements for arbitrary injection and doping," Journal of Applied Physics, vol. 95, pp. 1021-1028, 2004.

A. A. Istratov, H. Hieslmair, and E. R. Weber, "Iron contamination in silicon technology," Applied Physics A, vol. 70, pp. 489-534, 2000.

R. A. Sinton and A. Cuevas, "Contactless determination of current-voltage characteristics and minority-carrier lifetimes in semiconductors from quasi-steady-state photoconductance data," Applied Physics Letters, vol. 69, pp. 2510-2512, 1996.

L. Geerligs and D. Macdonald, "Dynamics of light-induced FeB pair dissociation in crystalline silicon," Applied Physics Letters, vol. 85, p. 5227, 2004.

J. D. Murphy and R. J. Falster, "The relaxation behaviour of supersaturated iron in single-crystal silicon at 500 to 750 [degree]C," Journal of Applied Physics, vol. 112, 113506, 2012.

A. A. Istratov, H. Hieslmair, and E. R. Weber, "Iron and its complexes in silicon," Applied Physics A, vol. 69, pp. 1344, 1999.

A. Liu, C. Sun, and D. Macdonald, "Hydrogen passivation of interstitial iron in boron-doped multicrystalline silicon during annealing," Journal of Applied Physics, vol. 116, $194902,2014$.

[16] S. P. Phang and D. Macdonald, "Direct comparison of boron, phosphorus, and aluminum gettering of iron in crystalline silicon," J. Appl. Phys., vol. 109, 073521, 2011.

[17] P. Karzel, A. Frey, S. Fritz, and G. Hahn, "Influence of hydrogen on interstitial iron concentration in multicrystalline silicon during annealing steps," Journal of Applied Physics, vol. 113, 114903, 2013.

[18] M. Al-Amin and J. D. Murphy, "Passivation Effects on Low-Temperature Gettering in Multicrystalline Silicon," IEEE Journal of Photovoltaics, vol. 7, pp. 68-77, 2017.

[19] C. Sun, A. Liu, S. P. Phang, F. E. Rougieux, and D. Macdonald, "Charge states of the reactants in the hydrogen passivation of interstitial iron in P-type crystalline silicon," Journal of Applied Physics, vol. 118, 085709, 2015. 
[20] J. D. Murphy and R. J. Falster, "Contamination of silicon by iron at temperatures below $800{ }^{\circ} \mathrm{C}, "$ Phys. Status Solidi $R R L$, vol. 5, pp. 370-372, 2011.

[21] F. Werner, B. Veith, D. Zielke, L. Kühnemund, C. Tegenkamp, M. Seibt, et al., "Electronic and chemical properties of the c-Si/Al2O3 interface," Journal of Applied Physics, vol. 109, 113701, 2011. 